\title{
Tuberkulosescreening nytter
}

\section{Screening av innvandrere fra land med høy forekomst av tuberkulose bidrar til å holde antall sykdomstilfeller lavt i mange land. Det viser en ny studie.}

I en kohort på over 500000 mennesker som innvandret til England, Wales og NordIrland i perioden 2006-12, er forekomst av tuberkulose og risikofaktorer for utvikling av sykdommen etter ankomst undersøkt (1).
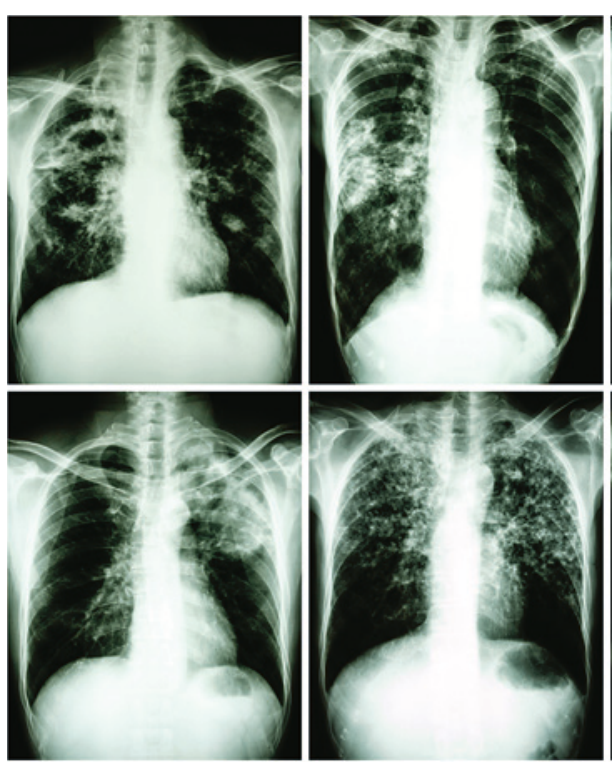

Illustrasjonsfoto: Thinkstock
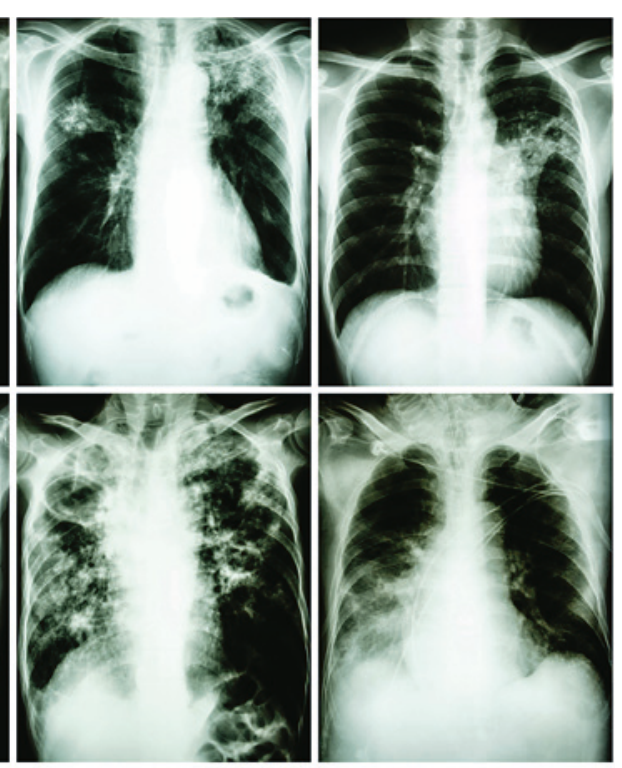

Alle studiedeltakerne var fra land med høy tuberkuloseforekomst, og de var undersøkt med røntgen av lungene før avreise fra hjemlandet. Ved røntgenfunn som tydet på tuberkulose, ble det tatt dyrkningsprøver, som måtte være negative før innreisetillatelse ble gitt.

Etter 2,45 år gjennomsnittlig oppfølging ble det påvist tuberkulose hos 1873 , tilsvarende en insidens på 147 tilfeller per 100000 personår (95\% KI 140-154). I en tilleggsanalyse var det kun 35 av rundt 300000 deltakere som hadde smittet andre etter at de hadde innvandret. De som hadde funn forenlig med aktiv tuberkulose på røntgenbildene, men negativ dyrkningsprøve ved screening før innreise, hadde om lag tre ganger så høy risiko for å få påvist sykdommen i løpet av de neste årene sammenlignet med dem som hadde normale funn. Risikoen var også større jo høyere forekomsten av tuberkulose var i deltakerens opprinnelsesland.

Forskerne bak studien konkluderer med at det ikke er smittespredning av betydning fra innvandrere som er screenet for tuberkulose. De mener oppfølging etter innvandring av dem med høyest risiko for utvikling av sykdommen kan bidra til å behandle flere og forebygge nye tilfeller.

\section{Matilde Risopatron Berg}

Sykehuset Innlandet, Hamar

\section{Litteratur}

1. Aldridge RW, Zenner D, White PJ et al. Tuberculosis in migrants moving from high-incidence to low-incidence countries: a population-based cohort study of 519955 migrants screened before entry to England, Wales, and Northern Ireland ancet 2016. E-publisert 11.10.2016.

\section{Genfeil bak intellektuell funksjonsnedsettelse}

\section{Eksomsekvensering hos mennes- ker med psykisk utviklingshemning kan ha terapeutiske konsekvenser.}

Årsaken til intellektuell funksjonsnedsettelse, tidligere kalt psykisk utviklingshemning, er ofte ukjent. Spesifikk behandling er derfor umulig. I en ny studie ble genomet til 41 personer med intellektuell funksjonsnedsettelse sekvensert og sammenholdt med kliniske og biokjemiske data (1). Hos om lag en tredel fant man en genetisk diagnose. Totalt ble det funnet 58 diagnostiske varianter i 42 forskjellige gener, og de fleste av disse var ikke tidligere registrert $\mathrm{i}$ genetiske databaser. Hos 18 personer førte genfunnet til endret behand- ling, bl.a. immunmodulerende behandling, folsyretilskudd eller levodopa.

- Denne studien er både inspirerende og oppløftende, sier David K. Bergsaker, som er overlege ved Frambu kompetansesenter for sjeldne diagnoser. - På Frambu er «utviklingshemning uten kjent årsak» en stor diagnosegruppe. Flere av disse personene har de siste årene fått spesifikke diagnoser takket være nye metoder. Denne studien viser at eksomsekvensering kan være svært nyttig når det benyttes $i$ et samarbeid mellom klinikere og genetikere og med god fenotypisk beskrivelse og bred metabolsk diagnostikk, sier han.

- Å få en årsaksdiagnose som forklaring på sammensatte vansker og utfordringer ved intellektuell funksjonsnedsettelse betyr mye for de pårørende, som ofte er på jakt etter en forklaring. En diagnostisk avklaring med terapeutiske implikasjoner, i form av for eksempel modifisert diett, kan ha stor betydning for den enkelte, for familiemedlemmer og for samfunnet. Eksakt diagnostikk er en forutsetning for kausal terapi, som etter hvert er blitt mulig ved flere og flere diagnoser, sier Bergsaker.

\section{Martine Rostadmo}

Tidsskriftet

\section{Litteratur}

1. Tarailo-Graovac M, Shyr C, Ross CJ et al. Exome sequencing and the management of neurometabolic disorders. N Engl J Med 2016; 374: 2246-55 